\title{
PHANTOM LIMBS AND THE BODY SCHEMA
}

\author{
Philip R. Bromage, f.f.A.R.C.s. * and Ronald Melzack, PH.D. $\nmid$
}

\section{INTRODUCTION}

AMPUTATED LIMBS persist as "phantoms" in their owners' consciousness. Temporary or permanent severance of afferent pathways may also give rise to subjective experiences in which the position of the phantom limb is different from that of the real one. ${ }^{1}$ Attempts have been made to explain phantom phenomena as expressions of a "body image" or "body schema" subserving a preconscious neurophysiological function. Varying interpretations have been placed upon the nature and behaviour of the theoretical body schema, but the original proposition of Head and Holmes remains the most satisfying. They proposed that the body image is formed and constantly changed by individual experience, and its role is a postural model, "against which all subsequent changes of posture are measured before they enter consciousness." ${ }^{2}$ No organized body of data exists to support the postural notion of the body schema, nor to define the limits of intrinsic plasticity proposed by Head and Holmes. ${ }^{3}$

In terms of phantom phenomena, definition of the body schema lacks an experimental model for pure deafferentation that is devoid of spurious neural information. Phantoms of traumatic or pathological origin are contaminated by uncontrolled peripheral input from neuromata, or from gliosis around central nervous lesions. Major conduction anaesthesia provides an attractive tool for reversible deafferentation in man, and phantom phenomena associated with spinal anaesthesia have been studied in the lower limb., ${ }^{4,5}$ The generally flexed phantom posture reported under these circumstances has been interpreted as a recent memory "fixation" arising from the position adopted immediately prior to deafferentation. ${ }^{5}$

Unfortunately, no technique of conduction anaesthesia can be relied upon to provide a complete and pure form of deafferentation. First, there is no neurophysiological assurance that blockade of all limb afferents is complete, even in the presence of adequate clinical anaesthesia. Second, local anaesthetic in the epidural or the subarachnoid space penetrates the superficial substance of the spinal cord, ${ }^{8}$ and this may produce partial blockade of descending pathways modulating proprioceptive information from lamina 6 of the dorsal horn. ${ }^{7}$ Nevertheless, with these reservations, conduction blockade remains the most useful method currently available for reversible deafferentation in man, and for the evocation of phantom phenomena.

We have observed the behaviour of phantom arms after deafferentation by brachial plexus anaesthesia, and phantom legs after epidural and subarachnoid anaesthesia. Our results lead us to agree with Holmes and Head's proposition

- Department of Anaesthesia, Royal Victoria Hospital, Montreal.

tDepartment of Psychology, McGill University

This study was presented at the Canadian Anaesthetists' Society Annual Meeting, June, 1973, in Vancouver, and was supported by M.R.C. Grant No. M.A. 1008. 
that the body schema subserves important postural functions, but we conclude that the nature of the schema is fixed, archetypal and possibly inherited, rather than plastic and acquired.

\section{METHODS}

The subjects were 6 volunteers and 104 patients undergoing surgery of the upper limb, and 59 patients undergoing surgery of the lower limb or abdomen. Upper limb anaesthesia was inducted by injecting $35-45 \mathrm{ml}$. of local anaesthetic solution into the fascial compartment of the brachial plexus at the level of the sixth cervical vertebra (interscalene approach), or as it crossed the first rib (supraclavicular approach). The subjects were supine, with arms stretched by the sides, as in the position of military attention. The following local anaesthetic agents were used according to the duration of anaesthesia required: 1 per cent lidocaine (hydrochloride or carbonate), 1 per cent mepivacaine hydrochloride, 0.25 per cent bupivacaine hydrochloride or 0.5 per cent etidocaine hydrochloride. All solutions contained 1/200,000 epinephrine.

Lower limb deafferentation was induced by epidural anaesthesia using 1.73 per cent carbonated lidocaine or 1 per cent etidocaine with $1 / 200,000$ epinephrine, injected at the second lumbar interspace, or by subarachnoid anaesthesia using 0.5 per cent tetracaine. The volume of solution used was calculated to provide anaesthesia up to a level between the tenth thoracic and fourth thoracic segments. ${ }^{8}$ Injection was made in the sitting position with the knees together, and the patients were placed with the legs horizontal, before the first sign of anaesthesia began to develop.

Phantom phenomena began to emerge when anaesthesia became fully developed about 10-30 minutes after induction of blockade. Subjects were asked to close their eyes, and to describe the subjective position of the limb, both with the anaesthetized arm by the side, and while the examiner manipulated the arm through a wide range of movements. Upper limb phantoms were tracked by asking the subjects to mimic the mirror-image position of the phantom, using the opposite unblocked arm as an indicator. Lower limb phantoms were described by the subjects and then plotted on coordinate charts, and the subjective distance between the two knees was noted. Phantom limb positions were recorded in terms of individual joint positions and were plotted on horizontal and vertical co-ordinates in degrees of arc (Figure 1). Modulation of phantom position by visual sensory input was tested by asking the subjects to look at the real limb.

\section{RESULTS}

Yield: The yield of phantoms was high after brachial plexus anaesthesia, with an incidence of 86 per cent, but it was low after epidural anaesthesia with an incidence of 10 per cent. Subarachnoid anaesthesia produced a yield of 55 per cent ( see Table I).

Position: Both upper and lower limb phantoms assumed attitudes of partial flexion, and rose in the air above the supine body. These attitudes were not modi- 


\section{Lower Limbs}
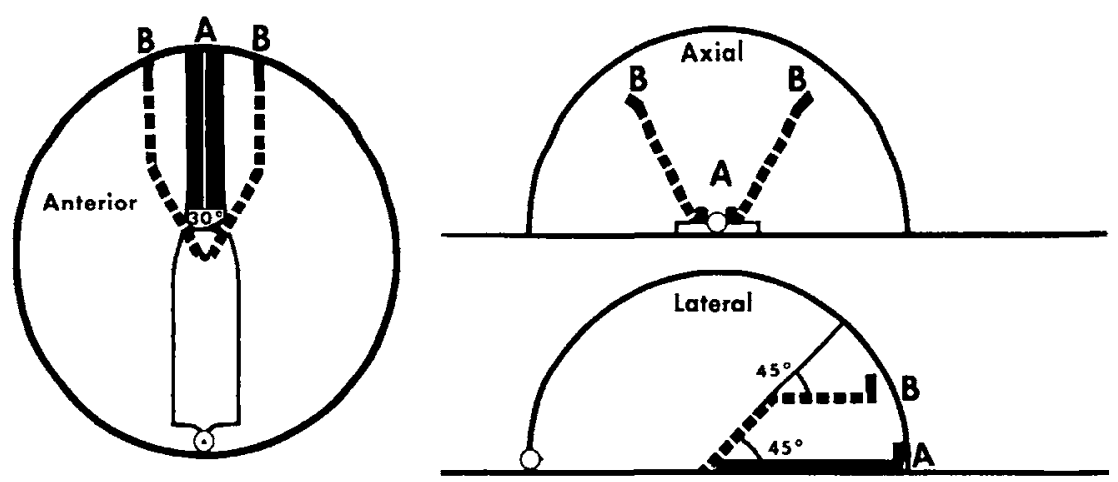

\section{Upper Limb}
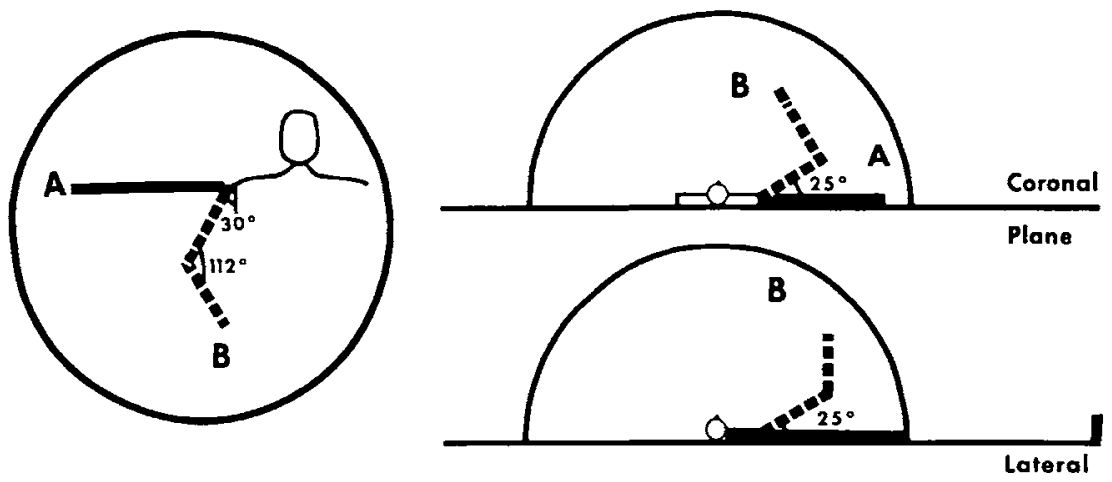

\section{$A=$ Real Limb \\ $B=$ Phantom}

Figure 1. Three dimensional coordinates for plotting subjective positions of phantom limbs and joint angles in relation to actual position of limb.

TABLE I

Incidence of Acute Phantom Limbs in Conduction Anaesthesia

\begin{tabular}{lccc}
\hline & No. of Blocks & \multicolumn{2}{c}{ Phantom Limbs } \\
\cline { 3 - 4 } Observed & No. & $\%$ Yield \\
\hline Arm & 110 & 95 & 86 \\
$\begin{array}{l}\text { (Brachial Plexus Blockade) } \\
\text { Leg }\end{array}$ & 50 & 5 & 10 \\
$\quad$ Epidural & 9 & 5 & 55 \\
\hline
\end{tabular}

fied by passive alteration of limb position. The phantom arms were partially flexed, abducted and internally rotated at the shoulder, and partially bent at the elbow, with the forearm midway between pronation and supination. Wrists were in the neutral position, with the fingers and thumb semi-flexed. The phantom 
TABLE II

Normal Range and Mid-Positions of JoInt Movement in Upper and Lower Limbs Compared with Observed Phantom Limb Positions after Deafferentation by Conduction Anaesthesia, Based ON DETaIled ANalysis of 70 Phantom Limbs

\begin{tabular}{|c|c|c|c|c|c|}
\hline \multirow[b]{3}{*}{ Joint } & \multirow[b]{3}{*}{ Movement } & \multicolumn{2}{|c|}{ Normal } & \multicolumn{2}{|c|}{ Phantom } \\
\hline & & Range & $\begin{array}{c}\text { Mid- } \\
\text { Position }\end{array}$ & Range & $\begin{array}{l}\text { Average Mid- } \\
\text { Position }\end{array}$ \\
\hline & & \multicolumn{2}{|c|}{ (Degrees of arc) } & \multicolumn{2}{|c|}{ (Degrees of arc) } \\
\hline \multirow[t]{3}{*}{ Glenohumeral } & $\begin{array}{l}\text { Vertical Extension- } \\
\text { Flexion }\end{array}$ & $0-90$ & $25^{*}$ & $10-70$ & 25 \\
\hline & Adduction-Abduction & $0-90$ & $25^{*}$ & $10-60$ & 30 \\
\hline & $\begin{array}{l}\text { Rotation: } \\
\text { Intra-Neutral-Ext. }\end{array}$ & $-90-+90$ & $-20^{*}$ & $-60-+30$ & -20 \\
\hline Elbow & Extension-Flexion & $0-150$ & 75 & $30-100$ & 68 \\
\hline $\begin{array}{l}\text { Inferior } \\
\text { radio-ulnar }\end{array}$ & Supination-Protonation & $90-90$ & 0 & $-30-+30$ & 0 \\
\hline \multirow[t]{2}{*}{ Wrist } & Extension-Flexion & $70-70$ & 0 & - & 0 \\
\hline & Deviation: Radial-ulnar & $25-30$ & 0 & - & 0 \\
\hline $\begin{array}{c}\text { Fingers \& } \\
\text { Thumb }\end{array}$ & Extension-Flexion & $0-90$ & 45 & $\begin{array}{l}\text { semi- } \\
\text { flexed }\end{array}$ & 45 \\
\hline \multirow[t]{2}{*}{ Hip } & Extension-Flexion & $-10-120$ & 55 & $30-60$ & 45 \\
\hline & Adduction-Abduction & $-30-+40$ & +15 & $+10-+20$ & +15 \\
\hline Knee & Extension-Flexion & $0-135$ & 67.5 & $30-80$ & 45 \\
\hline Ankle & $\begin{array}{l}\text { Dor siflexion- } \\
\text { Plantarflexion }\end{array}$ & \multicolumn{2}{|c|}{ Plantargrade } & \multicolumn{2}{|c|}{ Plantargrade } \\
\hline
\end{tabular}

All angles are referable to the coronal or sagittal planes.

*Corrected for $20^{\circ}$ forward tilt of anatomical gleno-humeral axis.

legs were semi-flexed at the hips and knees with the foot plantargrade. The hips were slightly abducted, with the knees 24 to $40 \mathrm{cms}$ apart. Seventy of 105 phantoms were closely observed in this way by one of us (PRB) and their positions are summarized in Table II, using the convention adopted by the American Association of Orthopedic Surgeons. ${ }^{9}$

From Table II it can be seen that the range of phantom positions for both the upper and lower limbs was restricted in relation to normal available joint range, and the phantoms were clustered within the middle 40 per cent to 70 per cent of joint movement. The average phantom position was close to the mid- or nullposition for each individual component of joint range. In the upper limb phantoms, there appears to be some discrepancy between the theoretical mid-position of the shoulder joint, and the observed positions of the phantoms. However, the coordinates chosen for convenience do not quite correspond to the anatomical axis of the glenohumeral joint, which is tilted forward about $20^{\circ}$ to $30^{\circ}$ anterior to the coronal plane. Thus, true glenohumeral co-ordinates require a corresponding correction. If this correction is applied the phantom shoulder measurements come closer to the true mid-joint position.

\section{Influence of Sensory Clues}

(A) Sensation arising distal to anaesthetized joints.

Technical considerations occasionally gave rise to situations where the proximal 
parts of the arm were thoroughly anaesthetized, but the distal parts were not. In these cases, sensory cues from the unanaesthetized hand would add intense conviction to the apparent reality of the phantom. For example, in one of us (PRB) a left interscalene block produced complete anaesthesia and motor blockade of the shoulder, upper arm and forearm, while the hand and fingers were relatively unanaesthetized. The subjective reality of the phantom hand became unequivocal as voluntary movements and sensations in the fingers reaffirmed the false position of the hand, which was felt to be stationed palm downwards and floating twelve inches above the left hip. In fact the arm had been manipulated by an observer so that the hand was palm upwards, above and behind the head at an arc of almost $180^{\circ}$ away from the phantom's apparent position.

(B) Visual Cues

When subjects are allowed to look at the anaesthetized limb the phantom usually leaves its station in an instantaneous, almost imperceptible movement and fuses with the real limb. Visual fusion does not always occur, and in 16 patients the phantom retained its ghostly station in spite of repeated instructions to look at the real arm and to concentrate upon it. In all of these 16 patients the degree of anaesthesia was intense, with complete motor and sensory blockade in all parts of the upper limb.

\section{Discussion}

The acute phantom behaviour observed in this study suggests that the body schema expressed in the nouminal, non-phenomenal phantom world has a universal nature that is remarkably stereotyped, with very little individual variation.

Acute anaesthetic phantoms differ fundamentally from post-amputation phantoms, and the behaviour of the two is quite different. In the anaesthetic phantom sensory cues are removed from the proximal joints of the limb. In amputees, on the other hand, distal tissues are lost, while the proximal surviving stump provides sensory data by which movements of a prosthesis can be tracked with remarkable accuracy. Thus, the anaesthetic limb is cut off from external reality by deafferentation of proximal structures, whereas the amputated limb is not. With incomplete anaesthetic blockade partial retention of sensory input may modulate phantom posture, and heighten the false subjective sense of phantom reality, as already discussed. In these cases the phantom sensation was easily overriden by visual cues and the phantom readily fused with the real position when the subject was told to open his eyes and to look at the anaesthetized arm. It is noteworthy that in all cases where visual fusion did not occur the quality of anaesthetic blockade was particularly intense and deafferentation appeared to be thoroughly complete.

This study has demonstrated that acute phantoms of the upper and lower limbs tend to adopt a position of orthopaedic rest. The ghostly, deafferented joints were clustered around the null position in the mid-range of joint movement, and none of them fell at the extremes of flexion or extension.

The mid-point of joint range is the position at which periarticular structures are least stressed, and at which both agonist and antagonist muscle groups are evenly balanced. In terms of neural information to the central nervous system 


\section{The Body Image}
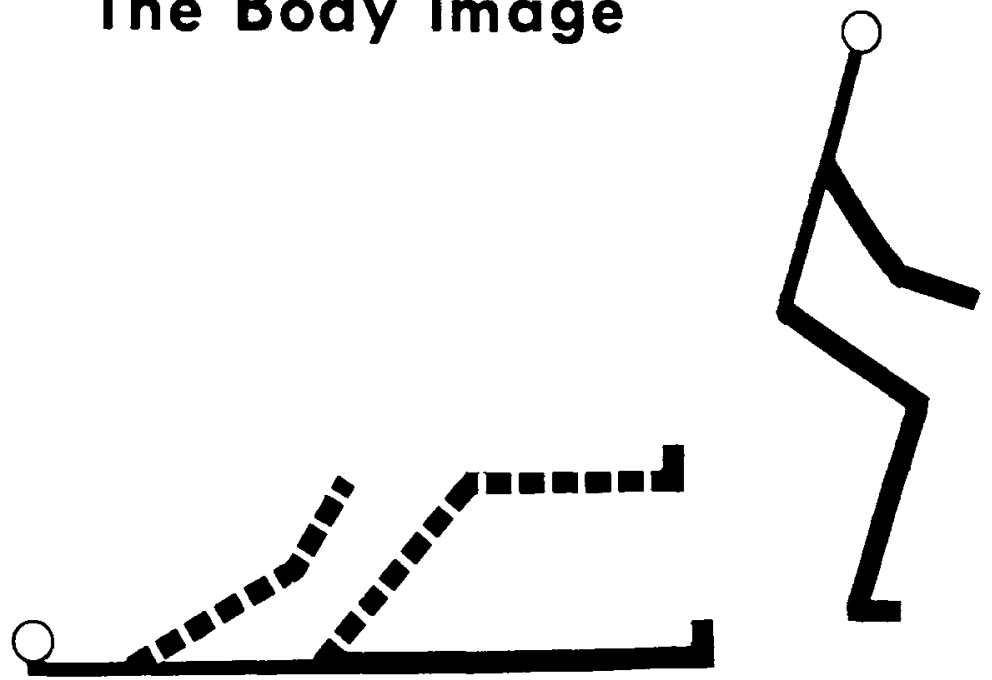

Ficure 2. Composite spatial homunculus of upper and lower limb phantoms in supine man. The position-of-rest is the position of action.

this is therefore the point at which net background afferent input from mechanoreceptors is minimal.10.11 At this point incremental information from very small changes of joint position may be expected to have maximal informative authority. This is in contradistinction to a joint that is flexed or extended away from the null position, where prestressing of mechanoreceptors will raise the background level of afferent input to an extent where small incremental changes will have less relative value. Looked at in this way, the phantom "position-of-rest" appears to be the one best suited as a template for posture in the real world of action, and it immediately acquires great functional significance. In this light the body schema is subservient to and waits upon objective reality. The nominal internal standard proposed by Head and Holmes is set at its most efficient point, and is poised for phenomenal instruction (Figure 2).

The origins of this internal standard are largely speculative but four theoretical possibilities may be considered.

It has been suggested by others that acute phantoms are merely a recent memory event, and that they adopt the position occupied by the limb immediately before anaesthetic blockade. ${ }^{5}$ Such an explanation is clearly unsatisfactory in the present series. All arm blocks were performed with the arm straight by the side, and yet none of our phantoms occupied this position. For anaesthesia of the lower limb epidural or subarachnoid injection was performed with the patient in the sitting position, and with the knees together. These patients were immediately placed in the horizontal position before anaesthesia developed. In all cases where a lower limb phantom developed, the hips and knees were felt to be semiflexed with the knees twelve to fifteen inches apart. Again, the posture of the phantoms did not correspond to that of the real limbs immediately prior to, or during the onset of blockade.

It is also unlikely that the internal body schema is a prenatal memory from the 
flexed position of the foetus in utero. The foetal position is one of extreme flexion and very different from the semi-flexed attitudes of the phantoms that we have observed.

The original concept of Head and Holmes postulated a plastic body schema, constantly changing, adapting and emerging in response to the stimuli of experience. Their internal standard was individual, impermanent, and essentially nonarchetypal. In contrast our observations show that the latent body image, as represented by acute phantom phenomena, is remarkably constant, with very little individual variation. However, these findings do not completely discount the possibility of an individual and acquired basis for the body image. It is conceivable that we are seeing the statistical mean for all body movements throughout a lifetime, whether that lifetime be eighteen years or eighty years, and that the average posture for everyone is highly predictable and stereotyped, with very little scatter around the mean.

The final possibility for our phantom origins is one of inherited neural memory from postural patterns laid down and selected throughout the history of man. We have pointed out that the position-of-rest is also the position of alert for instant action. Indeed, the posture of repose adopted by the phantom homunculus is strikingly similar to the stance of a wrestler or knife fighter balanced and crouched to spring. Such an internal standard would have great functional value as an instrument for swift response in a dangerous environment, and it is tempting to see it as a kinesthetic legacy in our inherited repertoire for violent survival. This last suggestion is not susceptible to proof, but we may be reminded of it every time we see the spatial homunculus emerge before our eyes at the start of a wrestling match, as the contestants square off with all limb joints at the positionof-rest.

\section{RÉSUMté}

En 1911, Head et Holmes suggéraient l'existence, au niveau de la préconscience, d'une image corporelle ou "schéma" jouant le rôle d'un modèle postural avec lequel tous les changements d'attitude étaient mesurés avant de pénétrer jusqu'à la conscience. Leurs observations étaient basées sur les perturbations subjectives de la sensation et sur les phénomènes fantômes survenant chez le amputés et chez les malades atteints de lésions du système nerveux central. Ils exprimaient l'avis que cette image ou représentation corporelle était façonnée par l'expérience kinesthésique de l'individu lui-même, ce schéma corporel s'apparentant à la moyenne arithmétique de tous les mouvements et de toutes les attitudes corporelles au cours de la vie. La position hautement stéréotypée des membres fantômes aigus nous a incités à mettre en doute l'origine purement individuelle de ce schéma corporel.

Des phénomènes fantômes de type aigu furent observés, en cours d'interruption des voies afférentes, chez 169 sujets soumis au blocage anesthésique d'un membre supérieur ou inférieur. Pour l'extrémité supérieure, dans 86 pour cent de blocages pleinement réussis du plexus brachial, des membres fantômes se manifestèrent lorsque les sujets fermaient les yeux. Quant à l'extrémité inférieure, des membres fantômes apparurent dans 55 pour cent des blocages sous-arachnoidiens, mais seulement dans 10 pour cent des blocages épiduraux. 
Les positions des membres fantômes dans l'espace furent inscrites selon des coordonnées à trois dimensions basées sur l'amplitude articulaire. Les membres fantômes avaient tendance à adopter une attitude de flexion partielle, cette attitude découlant du fait que chaque articulation fantôme se rapprochait d'une position intermédiaire ou indifférente. Aucun membre fantôme n'adopta des extrêmes de position. Contrairement aux rapports faits antérieurement par d'autres auteurs, les membres fantômes n'adoptèrent pas la position qu'affectait l'extrémité immédiatement avant linterruption des voies afférentes: en d'autres termes, les phénomènes fantômes n'étaient pas en relation avec une mémoire kinesthésique récente. Ils avaient tendance à être supprimés par des influences visuelles, le membre fantôme se confondant avec le membre véritable lorsque le sujet ouvrait les yeux et regardait son membre anesthésié.

Il est à signaler que la "position de repos" adoptée par les membres fantômes est aussi la position la plus efficace pour assurer rapidement les ajustements posturaux nécessaires à la défense ou à l'attaque. Il vient à l'esprit que le modèle stéréotypé du schéma corporel représente peut-être un legs kinesthésique héréditaire visant à la survivance dans un environnement de violence.

\section{ACKNOWLEDGMENTS}

Thanks are due to Dr. P.E. Otton for performing upper limb blocks upon the authors.

\section{REFERENCES}

1. Melzack, R. \& Bromage, P.R. Experimental phantom limbs. Experiment. Neurol. 39: 261-269 (1973).

2. HEAD, H. \& Holmes, G. Sensory disturbances from cerebral lesions. Brain 34: 102-254 (1912).

3. PoEck, K. \& Orgass, B. The concept of the body schema: a critical review and some experimental results. Cortex, 7: 254-277 (1971).

4. Wallgren, G.R. Phantom experience at spinal anaesthesia. Ann. Chir. Gyn. Fenn. 43: Suppl. 40; 486-500 (1954).

5. Prevoznik, S.J. \& Eckenhoff, J.E. Phantom sensations during spinal anaesthesia. Anesthesiology 25: 767-770 (1964).

6. Bromage, P.R., Joyal, A.C., \& Binney, J.C. Local Anesthetic drugs: penetration from the spinal extradural space into the neuraxis. Science 140: 392-394 (1963).

7. WALL, P.D. The laminar organization of the dorsal horn and effects of descending impulses. J. Physiol. 188: 403-423 (1967).

8. Bromage, P.R. Ageing and epidural dose requirements. Brit. J. Anaesth. 41: 1016-1022 (1969).

9. Joint Motion: Method of measuring and recording. American Academy of Orthopedic Surgeons (1965).

10. Boyd, I.A. \& RoBerTs, T.D.M. Proprioceptive discharges from stretch-receptors in the knee joint of the cat. J. Physiol. 122: 38-58 (1953).

11. Skoglund, S Anatomical and physiological studies of knee joint innervation in the cat. Acta physiol. Scandinav. 36: Suppl. 124: 1-100 (1956). 